\title{
Faktor faktor yang mempengaruhi pendapatan usaha ternak kambing di Kecamatan Pusomaen Kabupaten Minahasa Tenggara
}

\author{
C. Posumah, E Wantasen*, M. A. V. Manese, L. S. Kalangi \\ Fakultas Peternakan Universitas Sam Ratulangi Manado 95115 \\ *Korespondensi (corresponding author): erwinwantasen@yahoo.co.id
}

\begin{abstract}
ABSTRAK
Penelitian ini bertujuan untuk mengetahui pendapatan usaha ternak kambing serta faktor-faktor yang mempengaruhi pendapatan peternakan kambing di Kecamatan Pusomaen. Penelitian ini dilaksanakan di Kecamatan Pusomaen Kabupaten Minahasa Tenggara pada bulan Januari Februari 2020. Penelitian mengunakan metode survey di enam desa sampel yang dipilih secara purposive berdasarkan populasi ternak kambing terbesar. Pengumpulan data mengunakan teknik wawancara pada responden dengan menggunakan kuisioner yang telah disiapkan. Penentuan responden secara total sampling yaitu keseluruhan peternak kambing di enam desa lokasi penelitian yang berjumlah 58 orang peternak. Peternak kambing di Kecamatan Pusomaen memperoleh pendapatan rata rata Rp. 2.518.017,24/tahun pada rata rata pemilikan ternak 5 ekor, dengan rata-rata penerimaan dari hasil penjualan ternak kambing sebanyak Rp. 3.635.344,82/tahun, biaya produksi yang dikeluarkan oleh peternak sebesar Rp. 1.117.327,58/tahun. Faktor faktor yang secara parsial berpengaruh sangat nyata pada pendapatan usaha ternak kambing yaitu harga jual dan biaya pakan sedangkan jumlah ternak yang dijual berpengaruh nyata terhadap pendapatan usaha ternak kambing. Variabel dummy kesehatan ternak memberikan pengaruh yang tidah nyata terhadap pendapatan usaha ternak kambing
\end{abstract}

Kata Kunci: Pendapatan, peternak kambing.

\begin{abstract}
FACTORS INFLUENCING GOAT LIVESTOCK BUSINESS INCOME IN PUSOMAEN SUBDISTRICT SOUTHEAST MINAHASA REGENCY This study aims to determine the income of goat livestock as well as factors that affect the income of goat farms in Pusomaen Subdistrict. This research was conducted in Pusomaen Subdistrict, Southeast Minahasa Regency with a research period of one month, from January - February 2020. This study uses survey method. Data collection using interview techniques on goat breeder respondents using questionnaires that have been prepared. The method of determining the location of farmer samples was by purposive sampling on six villages that currently has biggest population of goat in this research site. Samples of breeders then were selected by total sampling sampling of all goat breeders in Pusomaen Subdistrict which amounts to 58 breeders. The average income gained by goat breeders in Pusomaen sub-district was IDR 2,518,017.24/year by ownership of 5 cattles, with the average revenue from the sale of goats as much as IDR. 3,635,344.82/year, production costs incurred by farmers amounted to IDR. 1,117,327.58/year Factors that have very significant effect on the income of goat livestock business was the selling price and feed costs
\end{abstract}


whereas the number of livestock sold had significant effect on farmers income from goat business

Keywords: Income, goat breeders, production cost

\section{PENDAHULUAN}

Konsumsi masyarakat terhadap daging terus mengalami peningkatan dan kebutuhan ini dipenuhi selain dari produksi dalam negeri juga dari impor. Di Indonesia ternak kambing mempunyai kemampuan kompetitif untuk bersaing dengan sumber daging sapi dalam memenuhi kebutuhan hidup manusia (kebutuhan gizi) dan merupakan alternatif penyedia daging yang perlu dipertimbangkan dimasa mendatang. Secara sosial penduduk Indonesia terbiasa mengkonsumsi daging kambing dan pada dasarnya kebutuhan domestik belum terpenuhi sehingga peningkatan produksi kambing akan terserap oleh pasar. Usaha ternak kambing sangat menguntungkan karena mempunyai jarak berana yang pendek sehingga cepat berproduksi dan dipasarkan. Selain itu dapat dijadikan sebagai sumber pendapatan tunai dan dapat beradaptasi dengan kondisi lingkungan (Umeta et al., 2011).

Penelitian sebelumnya oleh Murjito, et al. (2011) menyatakan bahwa hampir semua kambing di Indonesia dipelihara oleh petani kecil di pedesaan dalam skala kecil sekitar 2-7 ekor karena mereka hanya memiliki modal kecil. Lebih lanjut dikatakan bahwa sumber daya petani kecil terbatas dan terkendala secara bervariasi seperti kondisi pertanian, ketersediaan air dan kesuburan tanah, luas lahan serta jenis tanaman dan ternak (Verschelde et al., 2013). Namun demikian di yakini bahwa ternak yang dipelihara oleh petani kecil dapat digunakan untuk mengurangi kemiskinan, terutama di negara-negara miskin dan sedang berkembang (PicaCiamarra et al, 2015).
Maart-Noelck and Musshoff (2013) menyatakan bahwa dalam hal penggunaan investasi atau modal untuk memperluas usaha tani, petani memiliki kecenderungan untuk mempelajari investasi sebelumnya dan menilai apa yang diperoleh dari waktu ke waktu.

Penelitian Rusdi (2013), yang berjudul analisis pilihan masyarakat untuk beternak kambing di Desa Lempa, Kabupaten Wajo, dikemukakan bahwa masyarakat dalam menentukan pilihan untuk beternak kambing ditentukan oleh beberapa faktor yaitu faktor nilai ekonomis, peranan pemerintah, lahan, pakan, sosial budaya dan modal.

Kecamatan Pusomaen merupakan salah satu wilayah di Kabupaten Minahasa Tenggara yang memiliki populasi ternak kambing yaitu 276 ekor dengan jenis kambing kacang. Kecamatan Pusomaen memiliki 15 desa dan yang mempunyai ternak kambing hanya 6 desa, dengan jumlah peternak sebanyak 58 orang (BPS Minahasa Tenggara, 2019).

Berdasarkan hasil pengamatan di lokasi, cara pemeliharaan ternak kambing oleh peternak di Kecamatan Pusomaen masih bersifat tradisional sama halnya dengan daerah Indonesia lainnya yang belum mengenal cara pemeliharaan yang modern. Pemeliharaan yang dilakukan secara tradisional berlangsung dalam lingkungan keluarga dan pengawasannya dilakukan secara ekstensif, yang pada umumnya ternak kambing dilepaskan dan melakukan perkawinan bebas secara alam yang pada akhirnya berpengaruh pada penurunan mutu genetik ternak kambing. Penurunan mutu genetik ternak kambing akan mempengaruhi produktifitas sehingga 
secara tidak langsung akan berdampak pada penurunan terhadap pendapatan peternak. Ketersediaan hijauan masih terbatas berasal dari rumput lamtoro, kangkung, dan tanaman mangrove yang hanya diperoleh di sekitar desa. Sementara itu peternak kambing di Kecamatan Pusomaen masih banyak yang mengabaikan kondisi kesehatan ternak kambing yang mereka pelihara, karena baru sebagian kecil peternak yang sering memeriksakan kesehatan ternak kambing.

Harga jual ternak kambing berfluktuasi terutama pada saat hari raya Idul Adha dimana harga kambing cukup tinggi. Disisi lain kepemilikan oleh peternak sangat ditentukan oleh ketersediaan pakan. Peternak kambing di Kecamatan Pusomaen pada umumnya membeli pakan untuk ternak kambing disamping mengembalakan di sekitar desa. Jika pakan tersedia maka kambing akan mengalami pertumbuhan yang baik dan berpengaruh pada usaha tersebut. Peternak akan menjual ternak kambing jika membutuhkan biaya dalam rumah tangganya ataupun jika ada permintaan kambing misalnya di saat hari raya atau hari besar lainnya. Harga jual diduga dapat berpengaruh terhadap pendapatan yang diperoleh peternak kambing. Oleh karena itu penelitian ini perlu dilakukan untuk mengetahui faktor-faktor yang mempengaruhi pendapatan usaha ternak kambing dan besarnya pendapatan peternak di Kecamatan Pusomaen.

\section{METODE PENELITIAN}

\section{Lokasi dan waktu penelitian}

Penelitian ini dilaksanakan di Kecamatan Pusomaen Kabupaten Minahasa Tenggara. Waktu penelitian selama satu bulan, yaitu dari bulan Januari - Februari 2020.

\section{Metode pengumpulan data}

Penelitian dengan mengunakan
metode survey. Pengumpulan data
mengunakan teknik wawancara pada
responden peternak kambing dengan
menggunakan kuisioner yang telah
disiapkan.

\section{Jenis data dan sumber data}

Jenis Data yang dikumpulkan dari sumber data primer dan data sekunder. Data primer diperoleh dari hasil wawancara langsung dengan responden. Data primer dikumpulkan antara lain, karakteristik petani dalam usaha ternak kambing, jumlah ternak kambing yang dipelihara oleh responden, junlah ternak kambing yang dijual, biaya pakan. Data sekunder diperoleh dari dinas Pertanian dan Peternakan Kabupaten Minahasa Tenggara, dan Badan Pusat Statistik (BPS) Sulawesi utara serta data yang telah diolah oleh pihak lain, yaitu informasi mengenai data-data terkait dengan Objek penelitian, berbagai literatur, situs internet, buku-buku dan catatan yang berkaitan erat dengan ternak kambing.

\section{Metode penentuan sampel}

Metode penentuan lokasi sampel peternak adalah dengan purposive sampling pada enam desa di Kecamatan Pusomaen dengan pertimbangan memiliki populasi ternak kambing terbesar. (Umar et al, 2021) bahwa penentuan sampel secara purposive didasarkan pada pertimbangan tertentu sesuai dengan tujuan penelitian.. Sedangkan untuk penentuan responden adalah secara total sampling yaitu keseluruhan peternak kambing di Kecamatan Pusomaen yang berjumlah 58 orang peternak kambing yang tersebar di enam desa sampel. Menurut Sugiyono, (2017) sampling total adalah teknik penentuan sampel bila semua anggota populasi digunakan sebagai sampel. 


\section{Pengukuran variable}

1. Harga jual adalah penerimaan usaha ternak kambing, nilai jual ternak kambing oleh peternak (Rp/ekor).

2. Jumlah ternak adalah keseluruhan ternak kambing yang dimiliki peternak (ekor).

3. Biaya pakan adalah biaya yang dikeluarkan oleh peternak untuk membeli pakan rumput (Rp/tahun).

4. Jumlah ternak yang dijual adalah jumlah keseluruhan ternak kambing yang di jual dalam waktu satu tahun (ekor/tahun).

5. Dummy kesehatan ternak adalah $\mathrm{D}=1$ : pernah memeriksakan kesehatan, $\mathrm{D}=0$ : tidak pernah memeriksakan keshatan.

6. Biaya variable yaitu biaya pakan, vitamin dan obat-obatan yang diberikan untuk ternak kambing (Rp/tahun).

7. Total Biaya yaitu keseluruhan biaya tetap dan biaya variable yang dikeluarkan oleh peternak untuk usaha ternak kambing dalam suatu periode tertentu (Rp/tahun).

8. Pendapatan adalah selisih penerimaan dikurangi biaya produksi (Rp/tahun).

9. Penerimaan adalah jumlah total nilai penjualan ternak kambing yang diperoleh oleh peternak selama setahun (Rp/tahun).

\section{Analisis data}

Tujuan pertama adalah untuk mengetahui berapa besar pendapatan peternak kambing, digunakan rumus:

$$
\mathrm{Pd}=\mathrm{TR}-\mathrm{TC}
$$

Keterangan:

$\mathrm{Pd}=$ Total Pendapatan $(\mathrm{Rp} / \mathrm{thn})$

$\mathrm{TR}=$ Total Penerimaan $(\mathrm{Rp} / \mathrm{thn})$

$\mathrm{TC}=$ Total Biaya $(\mathrm{Rp} / \mathrm{thn})$

Dimana:

Penerimaan: Jumlah ternak kambing yang dijual dikalikan dengan harga jual (Rp/tahun).

Total Biaya: Semua pengorbanan yang dilakukan untuk suatu periode penjualan ternak kambing yang dinyatakan dengan satuan uang menurut harga pasar yang berlaku, baik yang terjadi maupun yang akan terjadi (Sugiyono 2014).

Tujuan kedua yaitu untuk

mengetahui faktor-faktor yang mempengaruhi pendapatan ternak kambing Kacang di Kecamatan Pusomaen dengan model persamaan sebagai berikut:

$Y=a+b_{1} X_{1}+b_{2} X_{2}+b_{3} X_{3}+b_{4} X_{4}+b_{5} X_{5}$ +e (Sugiyono, 2014)

Dimana:

$\mathrm{Y}=$ Pendapatan $(\mathrm{Rp} / \mathrm{thn})$

$\mathrm{X} 1$ = Harga jual (Rp/ekor)

$\mathrm{X} 2$ = Jumlah ternak yang dimiliki (ekor)

$\mathrm{X} 3$ = Biaya pakan (Rp/hari)

X4 = Jumlah ternak yang dijual (ekor/tahun)

$\mathrm{D}_{1}=$ Dummy kesehatan ternak (1: pernah memeriksakan kesehatan, 0: tidak pernah memeriksakan kesehatan).

e $=$ Standar error

a $=$ Intercep

b $=$ Koefisien Regresi.

Uji Signifikansi Simultan (Uji Statistik F)

Untuk mengetahui pengaruhpengaruh variable $\mathrm{X} 1, \mathrm{X} 2, \mathrm{X} 3, \mathrm{X} 4, \mathrm{X} 5$ secara bersama sama terhadap pendapatan usaha ternak kambing maka dilakukan uji $\mathrm{F}$. Uji statistik $F$ pada dasarnya menunjukan apakah semua variable independen yang dimasukan dalam modal mempunyayi pengaruh secara bersama-sama atau simultan terhadap variable dipenden. Hipotesis nol adalah join hypothesis bahwa $B 1, B 2 \ldots \ldots . B k$ secara simultan sama dengan nol.

HO: $B 1=B 2=\ldots \ldots . .=B k=0$

Pengujian hipotesis ini sering disebut pengujian signifikan keseluruhan terhadap garis regresi yang ingin menguji apakah Y secara linear berhubungan dengan X1, X2, X3, X4, X5.

Pengambilan keputusan:

Misalkan model regresi dengan k-variable $Y i=a+B 1 X 1 i+B 2 X 2 i+B 3 X 3 i+\ldots \ldots+$ $B k X k i+u i$

HO: $B 1=B 2=\ldots \ldots=B k=0$ 
(semua koefisien slope secara simultan sama dengan nol).

HA: tidak semua koefisien slope secara simultan sama dengan nol.

Hitung nilai $\mathrm{F}$ statistik dengan rumus:

$$
\mathrm{F}=\frac{E S S / d f}{R S S / d f}=\frac{E S S /(K-1)}{R S S /(n-k)}
$$

Jika $\mathrm{F}$ hitung $>\mathrm{F}$ tabel yaitu $F a(k-1$, $n-k)$ maka hipotesis nol ditolak. Di mana $F a$ $(k-1, n-k)$ adalah nilai kritis $\mathrm{F}$ pada tingkat signifikansi $a$ dan terjadi bebas (df) pembilang $(k-1)$ serta derajat bebas (df) penyebut $(n-k)$.

Terdapat hubungan yang erat antara koefisien determinasi $\left(\mathrm{R}^{2}\right)$ dan Nilai $F$ test. Secara matematis, nilai $F$ dapat juga dinyatakan dalam rumus seperti di bawah ini:

$$
F=\frac{R^{2}(K-1)}{\left(1-R^{2}\right)(n-k)}
$$

Berdasarkan rumus ini dapat disimpulkan jika $R^{2}=0$, maka $F$ juga sama dengan nol. Semakin besar nilai $\mathrm{R}^{2}$, maka semakin besar pula nilai F. Namum demikian jika $\mathrm{R}^{2}=1$, maka $\mathrm{F}$ menjadi tak terhingga. Jadi dapat disimpulkan uji $\mathrm{F}$ statistic yang mengukur signifikan secara keseluruhan dari garis regresi dapat juga digunakan untuk menguji signifikansi dari $\mathrm{R}^{2}$. Dengan kata lain pengujian $\mathrm{F}$ statistik sama dengan pengujian terhadap nilai $\mathrm{R}^{2}$ sama dengan nol.

Uji Signifikan Parameter Individual (Uji Statistik T)

Untuk mengetahui variable $\mathrm{X} 1, \mathrm{X} 2$, X3， X4， X5 secara parsial terhadap pendapatan usaha ternak kambing maka dilakukan analisis mengunakan uji $\mathrm{T}$. Uji statistik $t$ pada dasarnya menunjukan seberapa jauh pengaruh satu variable independen terhadap variable dependen dengan menganggap variable independen lainya konstan, jika asumsi normalitas error yaitu $\mu \mathrm{i} \sim \mathrm{N}\left(0, \sigma^{2}\right)$ terpenuhi, maka kita dapat mengunakan uji t untuk menguji koefisien parsial dari regresi. Misalkan kita ingin menguji apakah variable $\mathrm{X} 1$ berpengaruh terhadap $\mathrm{Y}$ dengan menganggap variable $\mathrm{X}$ lainya konstan:

HO: $B 1=0$ dan HA: $B 1 \neq 0$

$$
t=\frac{B 1}{\operatorname{se}(B 1)}
$$

Dimana $B 1$ adalah koefisien parameter dan se (B1) adalah standard error koefisien parameter. Jika nilai hitung $\mathrm{t}>$ nilai $\mathrm{t}$ tabel $\mathrm{t}$ $a$ adalah tingkat signifikansi dan $(n-k)$ derajad bebas yaitu jumlah $\mathrm{n}$ observasi dikurangi jumlah variable independen dalam model (Iman Ghosali dan Dwi Ratmono).

\section{HASIL DAN PEMBAHASAN}

\section{Keadaan umum wilayah dan lokasi penelitian}

Kabupaten Minahasa Tenggara adalah kabupaten di Provinsi Sulawesi Utara, Indonesia, dengan Ibukota Ratahan yang merupakan pemekaran dari Kabupaten Minahasa Selatan. Kabupaten Minahasa Tenggara adalah salah satu kabupaten di antara 15 kabupaten/kota (11 kabupaten dan 4 kota) yang ada di Provinsi Sulawesi Utara. Ibukota Kabupaten Minahasa Tenggara adalah Ratahan, berjarak sekitar $80 \mathrm{~km}$ dari Manado, ibu kota Provinsi Sulawesi Utara. Jumlah penduduk Minahasa Tenggara pada tahun 2019 berkisar 117.800 jiwa.

Kecamatan Pusomaen merupakan salah 1 dari 12 Kecamatan yang ada di Kabupaten Minahasa Tenggara dengan jumlah penduduk 9.375 penduduk.

\section{Karakeristik responden}

Unsur karateristik yang dikumpulkan dari responden antara lain umur, tinggkat pendidikan dan jenis pekerjaan. Data karakteristik dapat dilihat pada Table 1.

Umur peternak pada umur 2454yaitu sebanyak 35 orang $(60,34 \%)$ dari jumlah responden, sedangkan untuk 
peternak di umur 55 tahun keatas sebanyak 23 orang $(39,66 \%)$ dari jumlah responden. Pendidikan merupakan salah satu hal yang sangat penting dan sangat erat kaitannya dengan pembangunan sumber daya manusia yang baik. Tabel 2, menunjukan tingkat pendidikan peternak yang dijadikan responden paling banyak adalah tingkat SD yang berjumlah 31 orang $(53,44 \%)$, sedangkan pendidikan tingkat SMP berjumlah 12 orang $(20,68 \%)$, pendidikan tingkat SMA berjumlah 14 orang $(24,13 \%)$ dan pendidikan $\mathrm{S} 1$ berjumlah 1 orang $(1,72 \%)$. Kondisi umur tersebut mendukung usaha peternakan kambing yang dijalankan karena membutuhkan kemampuan fisik yang baik sehingga dapat maksimal dalam mengembangkan usaha peternakannya. Hal tersebut sesuai dengan pendapat Sumiati (2011) bahwa umur mempengaruhi kondisi fisik dan motivasi peternak. Kondisi fisik mempengaruhi kemampuan kerja seseorang peternak. Dengan demkian maka umur produktif mempunyai motivasi yang tinggi untuk mengetahui hal-hal baru yang belum diketahui dan memiliki kemampuan fisik untuk menerapkannya.

Tingkat pendidikan seseorang merupakan salah satu indikator yang mencerminkan kemampuan seorang untuk dapat melakukan dan menyelesaikansuatu jenis pekerjaan atau tanggung jawab yang diberikan kepadanya. Tingkat pendidikan akan berpengaruh terhadap pola pikir dalam melakukan pengambilan keputusan terhadap pola pikir dalam melakukan pengambilan keputusan terhadap usahanya. Hal ini sesuai dengan pendapat Hastang et al. (2018) bahwa dengan pendidikan akan menambah pengetahuan, pengembangan sikap dan menumbuhkan kepentingan peternak terutama dalam menghadapi perubahan.

Tabel 1. Karakteristik Responden Peternak Kambing Kacang di Kecamatan Pusomaen.

\begin{tabular}{clcc}
\hline $\mathrm{N}$ & & & \\
$\mathrm{O}$ & Karakteristik & Orang & Persentase \\
\hline 1 & Umur (Tahun) & & \\
& $24-54$ & 35 & $60,34 \%$ \\
& $>55$ & 25 & $39,65 \%$ \\
& Jumlah & 58 & $100 \%$ \\
2 & Pendidikan & 31 & \\
& SD & 12 & $53,44 \%$ \\
& SMP & 14 & $20,68 \%$ \\
SMA & 1 & $24,13 \%$ \\
& S1 & 58 & $1,72 \%$ \\
& Jumlah & & $100 \%$ \\
3 & Pekerjaan & 29 & \\
Nelayan & 13 & $50 \%$ \\
& Petani & 7 & $22,42 \%$ \\
Wirausaha & 1 & $12,06 \%$ \\
Pemandu & 6 & $1,72 \%$ \\
IRT & 58 & $10,34 \%$ \\
Jumlah & & $100 \%$ \\
\hline
\end{tabular}


Tingkat pendidikan akan mempengaruhi cara berpikir, mencari dan mencoba hal-hal yang baru.

Pekerjaan utama responden sesuai pada Tabel 1, yang paling banyak adalah sebagai nelayan yang berjumlah 29 orang $(50,00 \%)$ sedangkan pekerjaan sebagai petani berjumlah 13 orang $(22,41 \%)$, sedangkan pekerjaan sebagai wirausaha berjumlah 7 orang $(17,06 \%)$, sedangkan pekerjaan sebagai pemandu wisata berjumlah 1 orang $(1,72 \%)$ dan pekerjaan sebagai IRT berjumlah 6 orang (10,34\%). Dari jenis pekrjaan utama tersebut, responden hanya memelihara kambing kacang secara sambilan dan untuk menyalurkan hobi memelihara kambing kacang.

\section{Harga jual}

Harga merupakan pengorbanan ekonomis yang dilakukan pelanggan untuk memperoleh produk atau jasa. Menurut Kotler dalam Candra, (2017) penetapan harga jual adalah proses penentuan apa yang akan diterima suatu perusahaan dalam penjualan produknya. Dari definisi diatas dapat disimpulkan bahwa harga jual adalah sejumlah biaya yang dikeluarkan perusahaan untuk memproduksi suatu barang atau jasa ditambah dengan persentase laba yang diinginkan perusahaan, karena itu untuk mencapai laba yang diinginkan oleh perusahaan salah satu cara yang dilakukan untuk menarik minat konsumen adalah dengan cara menentukan harga yang tepat untuk produk yang terjual. Harga yang tepat adalah harga yang sesuai dengan kualitas produk suatu barang, dan harga tersebut dapat memberikan kepuasan kepada konsumen.

Harga jual ternak kambing di Kecamatan Posumaen di ukur berdasarkan umur dan jenis ternak kambing dimana untuk ternak kambing jantan umur 3-6 bulan berkisar antara Rp.350.000-
Rp.550.000/ekor, betina Rp.400.000Rp.600.000/ekor, ternak kambing umur 6-12 bulan jantan berkisar Rp.700.000Rp.950.000/ekor, betina Rp.700.000Rp.900.000/ekor, dan untuk ternak kambing berumur 12 bulan keatas jantan berkisar antara Rp.1.700.000-Rp.2.000.000/ekor, betina Rp.1.250.000-Rp.1.600.000/ekor.

\section{Biaya produksi}

Biaya produksi merupakan jumlah biaya yang dikeluarkan dalam suatu usaha untuk memperoleh produk. Biaya produksi terdiri dari biaya tetap dan biaya tidak tetap/variable. Biaya tetap merupakan biaya yang dikeluarkan untuk produksi yang besarnya tidak berpengaruh oleh jumlah produksi dan dapat dipergunakan dari satu kali proses produksi. Biaya tidak tetap/variable merupakan biaya yang dikeluarkan dalam satu kali masa produksi dan besarnya dipengaruhi oleh sejumlah produksi, yang termasuk biaya tidak tetap/ variable adalah biaya pakan, biaya obat, Sunardi dan Nonok, 2010). Biaya produksi peternakan kambing kacang Kecamatan Pusomaen dapat dilihat pada tabel 2.

Pada Tabel 2, dapat dilihat total biaya produksi kambing kacang di Kecamatan Pusomaen sebesar Rp. 64.805.000. Biaya pembelian bibit ternak kambing memiliki jumlah terbesar yaitu Rp. 33.650.000 pertahun. Sedangkan biaya pakan sebesar 30.276.000, biaya obat dan pemeriksaan kesehatan sebesar Rp. 879.000. Tenaga kerja yang digunakan dalam peternakan kambing kacang di Kecamatan Pusomaen merupakan tenaga kerja keluarga. Yusuf (2017) bahwa total biaya produksi berada pada responden dengan skala kepemilikan ternak >9 ekor yaitu rata-rata Rp. 7.322.478,-per peternak per tahun. Total biaya produksi terendah berada pada responden dengan skala kepemilkan ternak 1-4 ekor yaitu rata-rata Rp.2.884.495,-per tahun. 
Tabel 2. Biaya Produksi Peternakan Kambing

\begin{tabular}{lcc}
\hline Uraian & Rp/Tahun & Rata-rata biaya produksi (Rp/Tahun) \\
\hline Biaya variabel & & \\
a. Biaya pakan & 30.276 .000 & 522.000 \\
b. Biaya obat & 879.000 & 15.155 \\
Biaya tetap & & \\
a. Pembelian bibit kambing & 33.650 .000 & $580.172,41$ \\
\hline Total & 64.805 .000 & $1.117 .327,59$ \\
\hline
\end{tabular}

\section{Penerimaan}

Penerimaan usaha ternak kambing merupakan total hasil yang diperoleh peternak selama satu tahun masa pemeliharaan ternak kambing. Penerimaan tersebut dapat diperoleh dari berbagai sumber pada usaha peternakan kambing yang dijalankan atau dikerjakan.

Tabel 3, menunjukan jumlah penerimaan peternakan kambing kacang yang dipelihara di Kecamtan Pusomaen dari hasil penjualan kambing Kacang selama masa satu tahun sebesar Rp. 210.850.000, dengan rata-rata penerimaan perpeternak selama satu tahun sebesar Rp. 3.653.344,828 dan hasil dari penerimaan lain-lain tidak ada. Penelitian sebelumnya Yusuf (2017), penerimaan usaha ternak kambing terbesar pada skala kepemilikan >9 ekor yaitu Rp. 30.079.714,-per peternakper tahun. Kemudian skala kepemilikan 1-4 ekor merupakan penerimaan terendah yaitu hanya sebesar Rp. 6.795.238,-per peternakper tahun. Perbedaan penerimaan disebabkan oleh perbedaan besarnya populasi ternak kambing yang dimiliki oleh setiap peternak.

\section{Pendapatan}

Pendapatan adalah selisih antara penerimaan peternak dengan total biaya produksi yang dikeluarkan oleh peternak dengan hasil penerimaan peternak dikurangi dengan total biaya produksi. Hal itu sesuai dengan pendapat Miftahudin (2020) yang menyatakan bahwa pendapatan petani atau peternak adalah selisih antara penerimaan dengan semua biaya yang dikeluarkan selama melakukan kegiatan usaha.

Analisis pada Tabel 4, peternakan kambing Kacang di Kecamatan Pusomaen selama satu tahun memperoleh pendapatan sebanyak Rp. 146.237.000, dengan rata-rata pendapatan per peternak dalam satu tahun sebesar Rp. 2.518.017,241. Pada penelitian Yusuf (2017), pendapatan usaha ternak kambing terbesar berada pada responden dengan skala kepemilikan ternak $>9$ ekor yaitu Rp. 22.757.236,-per peternak per tahundan terkecil pada responden dengan skala kepemilikan ternak 1-4 ekor yaitu Rp. 3.910.743,-per peternak per tahun. Jika keuntungan dihitung per ekor ternak maka didapatkan hasil tertinggi tetap berada pada skala kepemilikan >9 ekor yaitu rata-rata Rp. 108.858,-per ekor ternakper bulandan keuntungan terkecil berada pada skala 1-4 ekor yaituRp.65.029,-per ekor per peternak.

\section{Faktor-faktor yang mempengaruhi pendapatan usaha ternak kambing}

Penelitian ini menggunakan metode linier berganda dalam menguji hipotesis yang di ajukan dengan program komputer SPSS 22. Hasil analisis disajikan pada Tabel 5. 
Tabel 3. Jumlah Penerimaan Peternak Kambing

\begin{tabular}{lcc}
\hline Uraian & $\mathrm{Rp} /$ Tahun & Rata-rata penerimaan $(\mathrm{Rp} /$ Tahun $)$ \\
\hline Penjualan ternak kambing & 210.850 .000 & $3.635 .344,83$ \\
\hline Total penerimaan & 210.850 .000 & $3.635 .344,83$ \\
\hline
\end{tabular}

Tabel 4. Jumlah Pendapatan Peternakan Kambing

\begin{tabular}{lcc}
\hline Uraian & Rp/Tahun & Rata-rata pendapatan (Rp/Tahun) \\
\hline Tptal penerimaan & 210.850 .000 & $3.635 .344,83$ \\
Total biaya & 64.805 .000 & $1.117 .327,59$ \\
\hline Pendapatan & 146.045 .000 & $2.518 .017,24$ \\
\hline
\end{tabular}

Hasil analisis regresi faktor-faktor yang mempengaruhi pendapatan usahatani ternak kambing, dimana variabel bebas yaitu harga jual $\left(\mathrm{X}_{1}\right)$, jumlah ternak yang dimiliki $\left(\mathrm{X}_{2}\right)$, biaya pakan $\left(\mathrm{X}_{3}\right)$, jumlah ternak yang dijual $\left(\mathrm{X}_{4}\right)$, dan dummy Kesehatan ternak $\left(\mathrm{X}_{5}\right)$, dijelaskan pada table 5 .

Berdasarkan hasil analisis regresi pada Tabel 5, diketahui bahwa secara bersama sama variabel harga jual, biaya pakan, jumlah ternak yang dimiiki, jumlah ternak yang di jual, dan dummy kesehatan ternak berpengaruh nyata pada pendapatan usaha ternak kambing $(\mathrm{P}<0,01)$. Hasil analisis regresi pada Tabel 6, juga menunjukan bahwa nilai $R^{2}$ sebesar 0,828 artinya variasi variabel harga jual $\left(\mathrm{X}_{1}\right)$, jumlah ternak yang dimiliki $\left(\mathrm{X}_{2}\right)$, biaya pakan $\left(\mathrm{X}_{3}\right)$, jumlah ternak yang dijual $\left(\mathrm{X}_{4}\right)$, dan dummy kesehatan ternak $\left(\mathrm{X}_{5}\right)$, berpengaruh terhadap variabel pendapatan (Y) sebesar $82,8 \%$, dan selebihnya yaitu sebesar $17,2 \%$ di pengaruhi oleh variasi variabel lain di luar model.

Selanjutnya dari hasil uji $\mathrm{t}$ pada tabel. 6, dapat dilihat faktor-faktor yang mempengaruhi pendapatan usaha ternak kambing di Kecamatan Pusomaen dijelaskan sebagai berikut.

\section{Harga jual $\left(\mathbf{X}_{1}\right)$.}

Hasil analisis menunjukan bahwa koefisien variabel haraga jual yaitu 0,971 artinya setiap pertambahan Rp. 100.000 harga jual, pendapatan bertambah sebesar Rp. 97.100. Hasil uji statistik menunjukan bahwa variable harga jual berpengaruh positif dan sangat nyata terhadap pendapatan usaha ternak kambing $(\mathrm{P}<0,01)$. Hasil tersebut sesuai pendapat Welerubun et al. (2016) bahwa peningkatan harga jual ternak mengakibatkan penerimaan peternak menjadi meningkat dan pendapatan yang diterima akan lebih besar.

\section{Jumlah ternak yang dimiliki $\left(\mathrm{X}_{2}\right)$.}

Hasil analisis menunjukan bahwa koefisien variabel jumlah ternak yang dimiliki adalah $-1,306$ artinya jika ternak bertambah $1 \%$ maka dapat mengakibatkan pengurangan pendapatan $1,306 \%$. Hasil uji statistik menunjukan bahwa variabel jumlah ternak yang dimiliki berpengaruh negatif dan tidak nyata terhadap pendapatan usaha ternak kambing $(\mathrm{P}<0,01)$. Jumlah pemilikan ternak berdampak pada penyedian pakan oleh peternak dimana sebagian pakan di beli oleh peternak. Hal ini berbeda dengan penelitian Kusrianto, (2010) dimana kepemilikan ternak kambing berpengaruh sangat nyata terhadap pendapatan usaha tani pada $\mathrm{p}<0,01$ di Desa Girikerto Kecamatan Turi Kabupaten Sleman.

\section{Biaya pakan (X3)}

Hasil analisis menunjukan bahwa koefisien variabel biaya pakan yaitu $-0,471$ artinya setiap penambahan Rp. 100.000 biaya pakan dapat mengurangi pendapatan 
Tabel 5. Hasil Analisis Regresi Faktor-Faktor Yang Mempengaruhi Pendapatan Usaha Ternak Kambing.

\begin{tabular}{lcrr}
\hline Variabel & Koefisien & t-hitung & \multicolumn{1}{c}{ Prob } \\
\hline Constanta & $-25.585,80$ & $-1,634$ & 0,108 \\
Harga jual (X1) & 0,971 & 16,959 & $0,000^{* * *}$ \\
Jumlah ternak yang dimiliki (X2) & $-1,306$ & $-0,07$ & 0,944 \\
Biaya Pakan (X3) & $-0,471$ & $-11,704$ & $0,000^{* * *}$ \\
Jumlah ternak yang dijual (X4) & 1,141 & 3,52 & $0,004^{* *}$ \\
Dumi kesehatan (X5) & 57.810 & 0,86 & 0,394 \\
F-hitung & \multicolumn{3}{c}{0,000} \\
R Square & kecil peternak menggunakan obat-obatan \\
\hline $\begin{array}{l}\text { Rp. 47.100. Hasil uji statistik menunjukan } \\
\text { bahwa variabel biaya pakan berpengaruh }\end{array}$ & dan melakukan pemeriksaan kesehatan \\
negatif dan sangat nyata terhadap & ternak untuk penanganan ternak kambing \\
pendapatan usaha ternak kambing (P<0,01). & nya dikarenakan sangat sedikit kasus \\
Hasil ini sejalan dengan penelitian Julpanijar & penyakit ternak serta pengetahuan peternak \\
et al. (2016) bahwa pakan berpengaruh & terhadap penanganan penyakit ternak. Hasil \\
terhadap pendapatan peternakan kambing. & ini berbeda dengan penelitian sebelumnya \\
Jumlah ternak yang dijual (X4) & Bangun et al. (2013) dimana variabel \\
$\quad$ Hasil analisis menunjukan bahwa & kesehatan berpengaruh terhadap pendapatan \\
koefisien variabel Jumlah ternak yang dijual & ternak kambing yang dipelihara dengan \\
sistem perkandangan.
\end{tabular}
yaitu 1,141 artinya setiap meningkatkan penjualan kambing $10 \%$ akan meningkatkan pendapatan peternak dari usaha ternak kambing 11,41\%. Hasil uji statistik menunjukan bahwa variabel jumlah ternak yang dijual berpengaruh positif dan nyata $(\mathrm{P}<0,05)$. Hasil penelitian Hausufah et al. (2015) dimana faktor jumlah ternak yang dijual berpengaruh sangat nyata terhadap pendapatan tunai usaha ternak kambing.

Dummy kesehatan ternak(X5)

Hasil analisis menunjukan bahwa koefisien variabel dummy kesehatan ternak yaitu 57.810 artinya peternak kambing yang memeriksakan kesehatan di saat kambing ketika sakit memperoleh pendapatan Rp. 57.810 lebih besar di banding peternak kambing yang tidak memeriksakan kesehatan kambing nya saat sakit. Hasil uji statistik menunjukan bahwa variabel dummy kesehatan ternak positif dan tidak nyata $(\mathrm{P}<0.05)$. Hal ini karena hanya sebagian

\section{KESIMPULAN}

Peternakan kambing di Kecamatan Pusomaen memperoleh pendapatan Rp. 146.237.000/tahun pada pemilikan ternak 5 ekor, dengan rata-rata penerimaan dari hasil penjualan ternak kambing sebanyak $\mathrm{Rp}$. 3.635.344,828/tahun, biaya produksi yang dikeluarkan oleh peternak sebesar $\mathrm{Rp}$. 1.117.327,586/tahun sehingga diperoleh pendapatan rata-rata satu tahun adalah Rp. 2.518.017,241. Faktor faktor yang berpengaruh nyata pada pendapatan usaha ternak kambing yaitu harga jual, biaya pakan sangat nyata pada $(\mathrm{P}<0,01)$ dan jumlah ternak yang dijual nyata pada $(\mathrm{P}<0,05)$ sedangkan jumlah ternak yang dimiliki dan dummy kesehatan ternak tidak berpengaruh.

\section{DAFTAR PUSTAKA}

Bangun E.S, T Sebayang dan Salmiah. 2013. Analisis produksi dan pendapatan 
usaha ternak kambing pedaging sistem kandang. Journal On Social Economic Of Agriculture And Agribusiness, 2(7):1-15.

BPS Kabupaten Minahasa Tenggara 2019. Kecamatan Posumaen dalam Angka 2019.

Candra P.K.G. 2017. Penentuan Harga Jual Kambing Peranakan Etawadi Pasar 17 Agustus Kabupaten Pamekasan. Skripsi, Program Studi Peternakan Fakultas Pertanian Universitas Madura Pamekasan.

Hausufah N, U.R. Lole dan S.M. Makandolu. 2015. Analisis faktorfaktor yang mempengaruhi pendapatan tunai usaha ternak kambing di Kabupaten Belu. Jurnal Nukleus Peternakan, 2(1):89-95.

Hastang, S Baba, A Asnawi dan M.I.A. Dagong. 2018. Karakteristik peternak kambing di Kecamatan Tamalatea, Kabupaten Jeneponto. Semnas Persepsi III Manado: 597603.

Julpanijar, Hasnudin dan A Rahman. 2016. Analisis pendapatan usaha ternak di Kecamatan Hinai Kabupaten Langkat.Jurnal Agrica, 4(1):9-19.

Kusriyanto Y. 2010. Faktor - Faktor Yang Mempengaruhi Pendapatan Usaha tani Terpadu Ternak Kambing Peranakan Ettawa Dan Salak Pondoh Di Desa Girikerto Kecamatan Turi Kabupaten Sleman. Skripsi, Universitas Gajah Mada.

Maart-Noelck, S.C. and O. Musshoff. 2013. Investing today or tomorrow an experimental approach to farmers'decision behaviour. Journal of Agricultural Economics 64 (2):295-318.

Miftahudi. 2020. Analisis ekonomi kambing etawa pola gaduhan: studi kasus di Desa Sukomulyo, Kecamatan Kajoran, Kabupaten Magelang.
Jurnal Paradigma Multidisipliner, 1(1):31-41.

Murdjito, G., I.G.S. Budisatria, Panjono, N. Ngadiyono and E. Baliarti. 2011. Performances of bligon goats kept byfarmers at Girisekar village, Panggang, Gunungkidul. Journal of Animal Science, 35 (2): 86-90.

Pica-Ciamarra, U., L. Tasciotti, J. Otte, and A. Zezza. 2015. Livestock in the household economy: crosscountry evidence from microeconomic data. Development Policy Review 33(1): 61-81.

Rusdi M, 2013. Analisis Pilihan Masyarakat Untuk Beternak Kambing Di Desa Lempa Kecamatan Pammana Kabupaten Wajo. Skripsi Fakultas Peternakan Universitas Hasanudin Makasar.

Sugiyono. (2017). Metode Penelitian Kuantitatif, Kualitatif, dan R\&D. Bandung: Alfabeta, CV.

Sugiyono, 2014. Metode Penelitian Kuantitatif Kualitatif, dan R\&D. Bandung.

Sumiati. 2011. Analisis Kelayakan Finansial Dan Faktor-Faktor Yang Memotivasi Petani Dalam Kegiatan Agroforesti. Tesis. Institut Pertanian Bogor.

Sunardi dan S. Nonok, 2010. Analisis pendapatan usaha ternak ayam potong di Kecamatan Karang Ploso. Bauna Sains 10(2): 167-174.

Umar H, J. Lainawa, G.D. Lenzun dan Z. Warow. 2021. Persepsi tokoh masyarakat dan peternak terhadap kinerja penyuluh dalam meningkatkan usaha peternakan sapi potong di Kecamatan Sangkub Kabupaten Bolaang Mongondow Utara. Zootec 41(1):44-52.

Umeta, F. Hundesa, M. Duguma and M. Muleta, 2011. Journal of Stored Products and Postharvest Research 2(8): 156-163. 
Verschelde, M., M. D'Haese, G. Rayp and E. Vandamme. 2013. Challenging small-scale farming: a nonparametric analysis of the (inverse) relationship between farm productivity and farm size in burundi. Journal of Agricultural Economics 64(2):319-342.

Welerubun I.N, T. Ekowati dan A. Setiadi. 2016. Faktor-faktor yang mempengaruhi pendapatan peternak domba kisar di Pulau Kisar Kabupaten Maluku BaratDaya.Jurnal Agromedia, 34(2): 54-64.

Yusuf R, 2017. Analisis Pendapatan Beternak Kambing Pada Berbagai Skala Kepemilikan Di Desa Palipi Soreang Kecamatan Banggae Kabupaten Majene. Skripsi Fakultas Peternakan Universitas Hasanuddin Makassar. 